Nadwa : Jurnal Pendidikan Islam

Vol. 13, No.2 (2019)

Accredited by Ristekdikti based on Decree No. 51/E/KPT/2017

DOI: 10.21580/nw.2019.13.2.4106

\title{
The Management of Strengthening the Mosque-Based Religious Character Education
}

\section{Badrudin}

UIN Sunan Gunung Djati Bandung

dr.badrudin@uinsgd.ac.id

\section{Abstract}

This study aims to explore the management of strengthening the religious character education of mosque-based students in madrasas. Data collection techniques using observation, interviews, and study documentation. Data analysis used qualitative analysis at Madrasah Aliyah Negeri 2 Kota Bandung. The results showed that the management of mosque-based character strengthening students had fulfilled management principles and was able to instill student character through worship activities. The design of activities to strengthen mosque-based character education that has been carried out includes thaharah, Duha praying, adhan, iqamah, recitation of asma alhusna, tadarus al-Quran, lectures, midday prayers, remembrance, and prayers. This activity is effectively able to develop the character of obedience, responsibility, discipline, cleanliness, neatness, trustworthy, confident, caring, brave and polite.

Keywords: Management; religious character; education; Mosque

\section{Abstrak}

Penelitian ini bertujuan untuk mengeksplorasi manajemen penguatan pendidikan karakter religius peserta didik berbasis Mesjid di madrasah. Teknik pengumpulan data menggunakan observasi, wawancara, dan studi dokumentasi. Analisis data menggunakan analisis kualitatif di Madrasah Aliyah Negeri 2 Kota Bandung. Hasil penelitian menunjukkan bahwa manajemen penguatan pendidikan karakter peserta didik berbasis masjid telah memenuhi prinsip manajemen dan mampu menanamkan karakter siswa melalui aktifitas ibadah. Desain aktivitas penguatan pendidikan karakter berbasis mesjid yang telah dilakukan meliputi thaharah, sholat Duha, adzan, iqamah, pembacaan asma alhusna, tadarus al-Quran, kuliah, sholat dzuhur, zikir, dan sholat. Kegiatan ini secara efektif mampu mengembangkan karakter kepatuhan, tanggung jawab, disiplin, kebersihan, kerapian, dapat dipercaya, percaya diri, peduli, berani dan sopan.

Keywords: Managemen; karakter religius; pendidikan; Mesjid 


\section{Introduction}

Historically, the mosque was the first Islamic educational institution in the time of the Prophet Muhammad that served as a center for character education laboratories as well as a place of worship. Among the mosques are Al-Haram Mosque and AnNabawi Mosque, which is followed by the presence of Islamic educational institutions such as al-Kuttab (a place to learn, to read, and to write letters of al-Quran)1. The mosque acts as a center for the development of the people 2. From that mosque, madrasa was developed, and had become a big role in education3.

The main character values in education include religious, nationalist, independent, mutual cooperation, and integrity values 4. According to the law, religious values are not equivalent to other values but are the basis for all values born from it5. In addition, religious values can also shape the discipline and independence of students 6 . Efforts to shape the value of religious character in enhancing students' faith include the strengthening of

1 Mahmud dan Tedi Priatna, "Kajian Epistemologi, Sistem dan Pemikiran Tokoh Pendidikan Islam", (Bandung: Azkia Pustaka Utama, 2008), 198-200.

2 Abdul Basit, "Strategi Pengembangan Masjid bagi Generasi Muda", $\begin{array}{lllll}\text { Jurnal Komunika, } & 3 & \text { No. } 2 & 2 & \text { (2009), }\end{array}$ Doi:10.24090/KOMUNIKA.V3I2.130.

3 Ginanjar dan Wartono, "Karakterestik Kepemimpinan Pendidikan Islam Berbasis Masjid”, Jurnal Manajemen Pendidikan Islam, I No. 1 (2018), 12. Doi: http://dx.doi.org/10.30868/im.v1i01.213.

4 M. Effendy, "Konsep dan Pedoman Penguatan Pendidikan Karakter", (Jakarta: Kementerian Pendidikan dan Kebudayaan Republik Indonesia, 2017), 8-9.

5 Erma Pawitasari, Endin Mujahidin, dan Nanang Fattah, "Pendidikan Karakter Bangsa dalam Perspektif Islam ...11. Doi: http://dx.doi.org/10.32832/tadibuna.v4i1.573.

6 Zulhairi, "Penanaman Nilai-nilai Karakter Peserta Didik di SMA Negeri 1 Padang Panjang," Jurnal al-Fikrah, 3 No. 2 (2015), 176. Doi: http://dx.doi.org/10.31958/jaf.v3i2.400. 
mosque-based character education for students. The strengthening of character education will run well if it is wellregulated and well-managed by madrassa.

All this time, character education has been carried out through learning7, including integrating the value of character education in Civic Education subjects8, integrating the value of character education in Biology subjects9, integrating the value of character education in religious education 10, and there is also integrating the value of character in al-Quran education 11. In contrast to other studies, the focus of this study is the management of strengthening the mosque-based religious character education of students.

The management of strengthening the mosque-based religious character education of students was implemented in one of the madrassa, the Madrasah Aliyah Negeri 2 Bandung, which the mosque activity programs has been established by the madrasa to strengthen the character education. This study seeks to explore and describe the planning, organizing, implementing, monitoring, and evaluating the strengthening of the mosque-

7 Angga, Bambang, A.Yusuf, "Implementasi Pendidkan Karakter dalam Pembelajaran di Sekolah Dasar," Jurnal Pendidikan Humaniora, 4 No.3 (2016), 134, http://journal.um.ac.id /index.php/jph/article/view/8214.

8 Suwito, "Integrasi Nilai Pendidikan Karakter dalam Mata Pelajaran Pendidikan Kewarganegaraan di Sekolah Melalui RPP," Jurnal Illmiah Civis, II No,2 (2012), 11. http://journal.upgris.ac.id/index.php/civis/article/view/454.

9 A. Machin, "Implementasi Pendekatan Saintifik, Penanaman Karakter dan Konservasi Pada Pembelajaran Materi Pertumbuhan," Jurnal Pendidikan IPA Indonesia, 3 No.1 (2014), 29. http://journal.unnes.ac.id/nju/index.php/jpii

10 Marzuki, Murdiono dan Samsuri, "Pembinaan Karakter Siswa Berbasis Pendidikan Agama di SD dan SMP DIY," Jurnal Kependudukan, 41 No.1 (2011), 46. Doi: https://doi.org/10.21831/jk.v41i1.1919.

11 Rosniati Hakim, "Pembentukan Karakter Peserta Didik Melalui Pendidikan Berbasis Al-Quran," Jurnal Pendidikan Karakter, IV No. 2 (2014), 124. Doi: https://doi.org/10.21831/jpk.v0i2.2788. 


\section{2 | Badrudin}

based religious character education for students in Madrasah Aliyah Negeri 2 Kota Bandung.

\section{Strengthening Students' Character Education}

Poerbakawatja and Harahap in Muhibbin Syah12 stated that education is a change in maturity to become responsible humans that are influenced by adult actions. The purpose of character education is to improve the quality of the educational process and outcomes which are core to the character of learners in a whole, integrated and balanced manner13.

Education could make students have a good character. Hamalik in Badrudinit stated that students are the input components that can be seen from various approaches, such as social, psychological and pedagogical aspect in the education system, which is processed through the education system so that they become qualified human beings in accordance with national education goals. In addition, Ramayulis 15 defines students as raw material in the process of transformation and internalization, to find the results of the educational process itself.

Character, according to Aristoteles in Thomas Lickona16, are actions that must be done correctly for oneself and others. As for Lickona, the character is "A reliable inner disposition to respond to situations in a morally good way. Character so conceived has

12 Muhibbin Syah., "Psikologi Pendidikan," (Bandung: PT Remaja Rosdakarya, 2107), 11.

13 E. Mulyasa, "Manajemen Pendidikan Karakter" Karakter" (Jakarta: Bumi Aksara, 2016), 9.

14 Badrudin, “Manajemen Peserta Didik," (Jakarta: Indeks, 2014), 22.

15 Ramayulis, Nizar dan Syamsul, "Filsafat Pendidikan Islam: Telaah Sistem Pendidikan dan Pemikiran Para Tokohnya," (Jakarta: Kalam Mulia, 2010), 169.

16 Thomas Lickona, "Educating for Character (Mendidik untuk Membentuk Karakter)” (Jakarta: Bumi Aksara, 2016), 81. 
three interrelated parts: moral knowing, moralfeeling, and moral behavior" 17 , that character is a condition to respond to something well. Character has three parts namely moral knowledge, moral feelings, and moral behavior. According to Aqib in Alif Laela Nez18, character building is done by understanding the meaning of kindness and good behavior in studentsren, building love and making moral knowledge into concrete actions. In an Islamic perspective, character theoretically has existed since Islam was revealed in the world, along with the sending of the Prophet Muhammad sallallaahu 'alaihi wa sallam19.

There are main values in the characters including religious, nationalist, independent, mutual cooperation, and integrity20. According to the law, religious values are not equivalent to other values, but are the basis for all values born from it21. Moreover, Suwito22 explained the values that need to be integrated into character education, including 1) Value of faith; 2) Value of devotion; 3) Value of Honesty; 4) Value of care; 5) Value of openness; 6) Value of togetherness; and 7) Ethical values.

To shape the character of students requires a real effort and a structured program. These efforts and programs can be found in strengthening the character education through guidance

17 Thomas Lickona, "Educating for Character: How Our School Can Teach Respect and Responsbility" (New York: Bantam Books, 1991), 51.

18 Alif Laela Nez, "Model Implementasi Pendidikan Karakter Berbasis Kurikulum 2013 di SMA Negeri 4 Kota Tegal,” Journal Unnes Educational $\begin{array}{lllll}\text { Management, } & 3 & \text { No.2 } & \text { (2014), } & 81 .\end{array}$ https://journal.unnes.ac.id/sju/index.php/eduman/article/view/4376.

19 E. Mulyasa, "Manajemen Pendidikan Karakter... 5.

20 M. Effendy, "Konsep dan Pedoman Penguatan Pendidikan ... 8-9.

21 Erma Pawitasari, Endin Mujahidin, dan Nanang Fattah, "Pendidikan Karakter Bangsa dalam Perspektif Islam ...11.

22 Suwito, "Integrasi Nilai Pendidikan Karakter dalam Mata Pelajaran Pendidikan Kewarganegaraan di Sekolah... 11. 
program. Guidance program is a real effort that is carried out programmed and consistently to achieve optimal results23. Guidance program can be done directly and indirectly. Direct Guidance program occurs when the builder and the coachee do face to face directly. The Guidance program does not directly occur if the coach uses the media in the guidance process 24.

The purpose of strengthening the character education is to improve human quality. These qualities include being a man of faith and devotion to Allah subhanahu wa ta'ala, being virtous, having good personality, being an independent, advanced, resilient, intelligent, creative, skilled, disciplined, work ethic, professional, responsible and proactive and physically and mentally healthy human being 25 .

\section{Management of Strengthening the Religious Character Education in Madrasa}

Strengthening religious character education in madrassa needs to be managed properly so that the aim to instill the value of religious character can be achieved effectively and efficiently. Thus, for this, guidance management discipline is needed. Management comes from the Latin "manus" which means hand

23 T.M. Sholiha, Narulita, dan Mardihah, "Peran Majelis Dhikr dalam Pembinaan Akhlak Remaja Putri," Jurnal Studi Al-Quran, 10 No.2 (2014), 148. http://journal.unj.ac.id/unj/index.php/jsq/article/view/4445.

24 S. Sylviyanah, "Pembinaan Akhlak Mulia pada Sekolah Dasar (Studi Deskriptif pada Sekolah Dasar Islam Terpadu Nur Al-Rahman)," Jurnal Tarbawi, 11 No. 3 (2012), 194-195. http://jurnal.upi.edu/tarbawi/view/1301/pembinaan-akhlak-mulia-padasekolah-dasar-studi-deskriptif-pada-sekolah-dasar-islam-terpadu-nur-alrahman-.html.

${ }_{25}$ S. Hendriani, Susi, Nulhaqim dan A.Soni, "Pengaruh Pelatihan dan Pembinaan dalam Menumbuhkan Jiwa Wirausaha Mitra Binaan PT Pelabuhan Indonesia I Cabang Dumai," Jurnal Kependudukan Padjadjaran, 10 No.2 (2008), 157. http://jurnal.unpad.ac.id/kependudukan/article/view/4032. 
and "agree" which means to do. The term management is absorbed from English, namely management and to manage. The management is carried out through a process that contains elements of management functions26. Furthermore, Ramayulis27 interpret management together with at-tadbir (arrangement) as in the word of Allah SWT., Q.S. As-Sajdah verse 5.

Management functions, in realizing character education, can be carried out through five stages as explained by Salim 28 including 1) Planning. The first step is to instill awareness about the importance of integrating character values in education. Then, it must be strengthened by regulations and / or policies explained by the head of madrasa so that all stakeholders are responsible for the learning process. 2) Organizing. The division of tasks and authority must be adjusted to the competencies, interests, talents and experiences and personalities of each stakeholder (the right man on the right place). 3) Actuating. In addition to character education, it is carried out in the learning process, and it also carried out through the acculturation of character values. In this case, all madrassa must become role models for students. The cultural activities of the character values are carried out continuously and consistently. 4) Controlling. The monitoring process is an important step to discuss findings in the field and provide solutions to overcome these findings. 5) Evaluating. Evaluation of character education should be carried out continuously and continuously.

26 Rusdiana dan Qiqi Yulianti Zakiah, "Manajemen Perkantoran Modern," (Bandung: Insan Komunika, 2014), 4.

27 Ramayulis, "Ilmu Pendidikan Islam,” (Jakarta: Kalam Mulia, 2008), 362.

28 A. Salim, "Manajemen Pendidikan Karakter di Madrasah (Sebuah Konsep dan Penerapannya)," Jurnal Tarbawi, 1 No.02 (2015), 10-14. https://www.neliti.com/id/publications/256501/manajemen-pendidikankarakter-di-madrasah. 
Character strengthening, according to Saptono29, needs to be done in madrassa or other formal institutions, bearing in mind that formal education institutions must carry out character education with the following reasons: 1) Character education is a bit carried out by families; 2) Formal education institutions (madrasa) also aim at forming good students in addition to being intelligent from an intellectual perspective; 3) Studentss' intelligence will be meaningful if accompanied by kindness; and 4) Building students' character is the responsibility of stakeholders, especially teachers.

\section{Mosque (Masjid) as an Institution for Strengthening Religious Character Education}

From an etymological the word mosque/ masjid comes from the Arabic vocabulary "sajada, yasjudu, sajdan", which means prostration. The mosque is a house of God that was built to remember, give thanks and worship Allah SWT for Moslems. In addition, the mosque is a place to do pious charitable activities, such as a place of deliberation, marriage, fortress and war strategy, and looking for solutions to the problems that are happening 30 . The term mosque is a term that was introduced directly by the Quran. In the Quran, the term mosque is mentioned twenty-eight times31.

As Moslems, the rapid growth of the mosque, indeed, becomes a proud achievement. Bahtiar in Najib, et al32 explained

29 Saptono, “Dimensi-dimensi Pendidikan Karakter, " (Salatiga:

Erlangga, 2011), 24.

30 Ismail, Asep Usman, Castrawijaya, dan Cecep, "Manajemen Masjid," (Bandung: Angkasa, 2010), 1-3.

31 A. Basit, "Strategi Pengembangan Masjid bagi Generasi Muda,"... 271.

32 M. Najib, Novan, dan Solichin, "Manajemen Masjid Sekolah sebagai Laboratorium Pendidikan Karakter bagi Peserta Didik," Jurnal Ta'dib XIX 
that it is really unfortunate, the existence of mosques in the community, offices, factories and especially in schools mostly only functioned as a place of worship. It is very rarely that the mosque is functioned as it should, such as a place of formation activities as exemplified by the Prophet Muhammad Saw. Thus, it can be said that the actual mosque in the school can be used as a medium in shaping the religious character of students.

\section{Mosque as a Basis for Strengthening Students' Religious Character Education}

The management of strengthening the mosque-based character education is management that is imbued with the value of a sincere spirit for God, be it the spirit of the congregation or the spirit of giving. The integrative educational process with the mosque will facilitate the inculcation of religious values, such as habituation of Duha praying, zuhr (midday) prayer and asr prayer in congregation for full-day school33. Strengthening the character is done as an effort in shaping the character of students34.

The spiritual character of students in madrasa will be formed by the strategies made by madrassa, one of which is mosquebased education management. This can be done by integrating character education into three aspects, including integration in

No.01 (2014), 86-87.

http://jurnal.radenfatah.ac.id/index.php/tadib/article/view/10.

33Tobroni, "Manajemen dan Kepemimpinan Pendidikan Islam ...26. Doi: http://dx.doi.org/10.21580/nw.2012.6.1.453.

34 Marzuki, Murdiono dan Samsuri, "Pembinaan Karakter Siswa Berbasis Pendidikan Agama di SD dan), ...7.

Doi: https://doi.org/10.21831/jk.v41i1.1919. 
each subject, integration in extracurricular activities and integration in habituation or example35.

Najib, et al36 explained the stages of strengthening the mosque-based religious character education of students, including planning, organizing. iplementation and evaluation.

\section{Planning to Strengthen the Mosque-Based Religious Character Education for Students}

The planning process for strengthening the mosque-based religious character education of students in Madrasah Aliyah Negeri 2 Bandung is carried out in three stages, including identifying the character needs of learners, developing character education materials, and developing the design of implementing the following character education strengthening activities:

Identification of the Need for Strengthening the Religious Character Education of Students

Planning to strengthen the mosque-based religious character education of students in Madrasah Aliyah Negeri 2 Bandung is inseparable from the vision, mission, goals of the madrasa and the purpose of education, which is to shape the character of the students. The plan is in line with Muhibbudin 37 which states that in planning the first step that must be considered is setting goals.

Madrasas need mosque-based activities so that religious practice can be carried out effectively in order to establish

35 E. Mulyasa, “Manajemen Pendidikan Karakter ...268.

36M. Najib, Novan, dan Solichin, "Manajemen Masjid ...94. http://jurnal.radenfatah.ac.id/index.php/tadib/article/view/10.

37Muhibbudin Abdul Muid, "Manajemen Pendidikan" (Batang: Pengging Mangkunegara, 2013), 6-9. 
excellent and qualified individuals38. Thus, Madrasah Aliyah Negeri 2 Bandung design program activities to strengthen the religious character education of students centered on the mosque. These activities include:

Tabel 1 Mosque Based Activities Program

\begin{tabular}{|c|l|l|}
\hline No & \multicolumn{1}{|c|}{$\begin{array}{c}\text { The Name of the } \\
\text { Program }\end{array}$} & \multicolumn{1}{c|}{ Character Values } \\
\hline 1. & $\begin{array}{l}\text { Thaharah } \\
\text { (before praying) }\end{array}$ & $\begin{array}{l}\text { Love \& maintain cleanliness, } \\
\text { responsible, liveorderly, and practicing } \\
\text { patient with queuing culture. In line } \\
\text { with the opinion of Najib, et al 39. }\end{array}$ \\
\hline 2. & $\begin{array}{l}\text { Duha praying in } \\
\text { congregation (Tuesday- } \\
\text { Thursday) }\end{array}$ & $\begin{array}{l}\text { Responsibility, compliance, discipline, } \\
\text { cleanliness, neatness, and } \\
\text { trustworthiness. }\end{array}$ \\
\hline 3. & $\begin{array}{l}\text { Azan and iqamah (held by } \\
\text { each class). }\end{array}$ & $\begin{array}{l}\text { Obedience, responsibility, confidence, } \\
\text { tasamuh, brave, polite and trustworthy. } \\
\text { In line with the opinion of Najib, et al } \\
\text { 40. }\end{array}$ \\
\hline 4. & $\begin{array}{l}\text { Seven minutes lecture } \\
\text { (Kultum) } \\
\text { Representative of each } \\
\text { class) }\end{array}$ & $\begin{array}{l}\text { Obedience, responsibility, courage, } \\
\text { tasamuh, self-confidence, never give } \\
\text { up, work hard, and good manners. In } \\
\text { line with the opinion of Najib, et al 41. }\end{array}$ \\
\hline 5. & $\begin{array}{l}\text { Reciting al-Quran } \\
\text { (Before prayer) }\end{array}$ & $\begin{array}{l}\text { Discipline, perseverance, and } \\
\text { responsibility, as explained by Najib et } \\
\text { al 42. }\end{array}$ \\
\hline
\end{tabular}

38 M. Zulfa, "Transformasi dan Pemberdayaan Umat Berbasis Masjid: Studi Pada Masjid Nurussa'adah Salatiga," Jurnal Penelitian Sosial Keagamaan, 9 No. 1 (2015), 261. Doi: 10.18326/infsl3.v9i1.257-278.

39 M. Najib, Wiyani, dan Solichin, "Manajemen Masjid Sekolah...94. http://jurnal.radenfatah.ac.id/index.php/tadib/article/view/10.

40 M. Najib, Wiyani, dan Solichin, "Manajemen Masjid Sekolah...95. http://jurnal.radenfatah.ac.id/index.php/tadib/article/view/10.

41 M. Najib, Wiyani, dan Solichin, "Manajemen Masjid Sekolah...96. http://jurnal.radenfatah.ac.id/index.php/tadib/article/view/10.

42 M. Najib, Wiyani, dan Solichin, "Manajemen Masjid Sekolah...96. http://jurnal.radenfatah.ac.id/index.php/tadib/article/view/10. 


\begin{tabular}{|c|l|lr|}
\hline 6. & $\begin{array}{l}\text { Reciting asma al-husna } \\
\text { (After adhan) }\end{array}$ & $\begin{array}{l}\text { Responsibility, honesty, and } \\
\text { discipline. }\end{array}$ \\
\hline 7. & $\begin{array}{l}\text { Zuhr (Midday) prayer in } \\
\text { congregation }\end{array}$ & $\begin{array}{l}\text { Discipline, responsibility, order, } \\
\text { friendship, and integrity. }\end{array}$ \\
\hline 8. & Dhikr and Dua (Prayer) & $\begin{array}{l}\text { Discipline, obedience, and } \\
\text { introspective. In line with the opinion } \\
\text { of Najib, et al 43. }\end{array}$ \\
\hline
\end{tabular}

Source: Managed by Researcher

\section{The Development of Character Education Materials}

The development of character education materials in Madrasah Aliyah Negeri 2 Bandung is carried out by integrating through subjects, extracurricular and habituation. To find out about this development, a meeting was held with educators and parents. Meetings with educators aim to develop character values according to the needs of students which will be outlined in core competencies (KI) and basic comptencies (KD). The meeting with parents aims so that parents can help the process of growing the students' character well. To strengthen the mosque-based religious character education, students are included in the form of habituation.

The Development of Implementation Plan for Strengthening Religious Character Education Activities

The development of the design of the implementation of activities to strengthen religious character education is conducted through a program of mosque activities including thaharah, Duha praying in congregation, call to prayer (azan) and iqomah, seven minutes lecture (kultum), reciting al-Quran, recitation of al-asma al-husna, zuhr prayer in congregation and $d h i k r$ and prayer ( $d u^{\prime} a$ ). Program planning to strengthen the mosque-based religious character education for students is integrated with planned

43 M. Najib, Wiyani, dan Solichin, "Manajemen Masjid Sekolah...96. http://jurnal.radenfatah.ac.id/index.php/tadib/article/view/10. 
learning programs such as Duha praying and Dhuhr prayer in congregation. The division of class time is initially 45 minutes for one hour subject, specifically for the morning schedule, from 07.00 WIB until 07.45 WIB to 07.00 WIB until 07.30 WIB because 30 minutes is used for the Duha praying together. Hence, learning activities begin at $07.30 \mathrm{WIB}$ on Tuesday for class XII, on Wednesday for class XI and on Thursday for class X.

\section{Organizing the Strengthening of the Mosque-Based Religious Character Education for Students}

Organizing in Madrasah Aliyah Negeri 2 Bandung is done through the formation of the madrasa organizational structure and the preparation of the main tasks of the organizational structure. Organizing the strengthening of the mosque-based religious character education for students in Madrasah Aliyah Negeri 2 Bandung is adjusted to the tasks, competencies, interests, talents, and personalities of each stakeholder (the right man on the right place). This condition is in line with Salim44 which states that the division of tasks and authority must be adjusted to the competencies, interests, talents of each stakeholder. Organizing the strengthening of mosque-based religious character education for students is carried out by all madrassa including the madrasa principle as the main responsible, madrasa vice principle of curriculum, madrasa vice principle of student affairs, madrasa vice principle for infrastructure, madrasa vice principle of public relations, supervisor religion, educators and education staff, and students. In addition, strengthening the mosque-based religious character education is assisted by a team of Isslah extracurricular

44 A. Salim, "Manajemen Pendidikan Karakter di Madrasah...10-14. https://www.neliti.com/id/publications/256501/manajemen-pendidikankarakter-di-madrasah. 


\section{2 | Badrudin}

members whose aim is to foster and improve the quality of students.

\section{The Implementation of Strengthening the Mosque-Based Religious Character Education for Students}

The implementation of strengthening the mosque-based religious character education of students includes program activities such as Duha praying in congregation, dhuhr (midday) prayer, adhan, kultum, iqamah, recitation of al-asma al-husna, reciting the holy Quran, dhikr and prayer, and Friday prayers.

The program to strengthen mosque-based character education begins with Duha praying in congregation program. The Duha praying in congregation takes place from 07.00 - 07.30 WIB. The learning process in the morning hours will be interrupted for 30 minutes to pray duha. However, creative educators in choosing learning methods, so that learning material is not reduced.

The Duha praying prayer in congregation is held every Tuesday to Thursday because Monday is filled with a flag ceremony. As for Tuesday the implementation of the Duha praying for class XII, Wednesday for class XI, and Thursday for class X. For disciplining students from each class as scheduled in the Madrasah Aliyah Negeri 2 Bandung in carrying out the Duha praying activities assisted by madrasa vice principle of student affairs that brings a whistle as a sign to immediately gather at the mosque, meanwhile students who do not have ablution immediately perform ablution first.

Students who have gathered at the mosque immediately read the Quran. The habit of reciting al-Quran before prayer has a character value which is to be a person who has faith, pious, good at reading and writing of the Quran and has good character. This 
is in line with the opinion of Hakim45 that reading the Quran can make a person of faith, piety, good reading and writing of the Quran, and noble. After completing the program, the Duha praying is performed together accompanied by the assigned teaching staff. Then proceed to read the prayer led by one person assigned. Character values obtained from the Duha praying together based on the results of interpretation with the resource persons are the value of togetherness, the value of obedience, the value of discipline, the value of mutual cooperation, all of which are summarized in religious values.

Besides the Duha praying in congregation program, in order to strengthening the mosque-based religious character education for students, there is also the custom of the midday prayer. This habituation is carried out after the second rest hour ie when the time of noon comes. Praying in congregation, as Ginanjar \& Wartono46 stated, has the principle of $u k h u w a h$, the principle of musawah and the principle of Imamat. The principle of $u k h u w a h$ has the meaning that with congregational prayers the values of togetherness and fraternity in Islam will form, while the principle of musawah has equality before God. This musawah principle is applied in Madrasah Aliyah Negeri 2 Bandung by not considering who the student is, which means, if they break the rules of the madrasa, they will be given a punishment. The principle of Imamat is seen in the congregational prayer which requires the existence of an Imam.

The midday prayer is performed after the second break. All madrasa residents stopped for a moment in carrying out the work

45 Rosniati Hakim, "Pembentukan Karakter Peserta Didik Melalui Pendidikan Berbasis Al-Quran,” Jurnal Pendidikan Karakter, IV No. 2 (2014), 124. Doi: https://doi.org/10.21831/jpk.v0i2.2788.

46 M.H.Ginanjar dan Wartono, "Karakteristik Kepemimpinan Pendidikan Islam... 13-14. Doi: http://dx.doi.org/10.30868/im.v1i01.213. 


\section{4 | Badrudin}

and immediately got ready to take ablution to perform the midday prayer. Strengthening character education is seen when the bell rings for the second break because students get used to take ablution immediately. Ablution has the value of love of cleanliness, the value of patience because it must be queued and the value of discipline in doing the pillars of ablution.

Conditioning students to perform ablution immediately is inseparable from the role of teaching staff, especially student coaches with the characteristic of carrying a whistle. After all madrasa residents have ablution and gather in the mosque, students who have been assigned to the call to prayer and kultum from each class have to wait in advance at the mosque.

Adhan (muadzin) officers in Madrasah Aliyah Negeri 2 Bandung come from students sent by each class. The character values contained in the call to prayer are the values of responsibility, courage, discipline, honesty, and togetherness. The character value obtained by the midday prayer is the value of respect. This is done by listening to the muezzin then answering the call to prayer. In line with Toto in Majid \& Andayani47, the value of respect and respect is part of moral loving.

After the call to pray, the sunnah rowatib qabla dzuhr is accustomed to, then the character habituation continues to the reading of al-asma al-husna led by one person, and the congregation of dzuhr sahalat follows the reciting of al-asma alhusna. After reciting al-asma al-husna, the midday prayers are accustomed to reciting the verses of the Quran. Al-asma al-husna recitation contains character values such as discipline, honesty and togetherness. The character values contained in reciting Quran include discipline, perseverance and responsibility, as Islam...34.

47 A.Majid dan D.Andayani, "Pendidikan Karakter Persepektif 
explained by Najib et al48. Reciting Quran is not only done in mosques but in other forms of habituation as a form of disciplining students as when starting learning and reciting Quran is given as a form of punishment for those who are late coming to madrasa.

The activity of strengthening the religious character education of students is continued with cultural activities. Students who have been assigned to give kultum, immediately take to the stand to deliver their lecture for seven minutes. The customization of the kultum, according to the informant, aims to train students' mentality so that they have a brave spirit in the amar ma'aruf nahyi munkar. In addition, the character values for the kultum are obedience, responsibility, courage, tasamuh, selfconfidence, never giving up, working hard, and good manners. As for those who listen to more focus on the value of respect. Respect value according to Muchlas and Haryanto is part of the taste 49.

After the kultum activity, the officer of the students who had been assigned to announce iqamah immediately in the future. Iqamah is a call that prayer in the congregation will soon be held. Iqamah recitation in one package with the call to prayer. In Madrasah Aliyah Negeri 2 Bandung City the character values of iqamah that can be internalized in the souls of students are the value of discipline, the value of obedience, the value of responsibility, respect, and the value of courtesy. This is in line with Najib's opinion that iqomah has the value of obedience, responsibility, respect and courtesy50.

48 M. Najib, Wiyani, dan Solichin, "Manajemen Masjid Sekolah...96. http://jurnal.radenfatah.ac.id/index.php/tadib/article/view/10.

49 Muchlas S., dan Hariyanto, "Konsep dan Model Pendidikan Karakter" (Bandung: PT Remaja Rosdakarya, 2017), 25.

50 M. Najib, Wiyani, dan Solichin, "Manajemen Masjid Sekolah...95. http://jurnal.radenfatah.ac.id/index.php/tadib/article/view/10. 
After iqamah, the imam leads the prayer from the first rak'ah to the fourth rak'ah. After the midday prayer, a dhikr and prayer are made. Recitation of dhikr and prayer led by one person and worshipers followed. The practice of dhikr and prayer is done so that students have a disciplined, obedient, and introspective spirit. Then accompanied by educators, students who have prayed and dhikr, are accustomed to performing the rawatiba sunnah prayer.

Dhikr and prayer are part of a mosque-based religious character education program which is usually done after the prayer. Dhikr and prayer have character values that can be internalized in students such as self-awareness, discipline, and obedience. This is in line with Najib's opinion that dhikr and prayer have the value of obedience and introspection for students51. In addition, students besides doing dhikr and prayer when they finish praying, are also expected to be able to get used to it in their daily activities.

Besides the programs to strengthen the mosque-based character education of students that have been explainned, Madrasah Aliyah Negeri 2 Bandung also has a routine program every Friday namely Friday prayers. Friday prayers are required for all men and their implementers in the mosque of Madrasah Aliyah Negeri 2 Bandung City. The female students are also going to the mosque, but they are only required to listening to the khutbah, which should be written by female students. For female students who are unable to attend, they are included in the cermin (mini-lecture) program conducted in the classroom guided by educators and Isslah members. Cermin can be in the form of scientific sharing, lectures, and vent.

51 M. Najib, Wiyani, dan Solichin, "Manajemen Masjid Sekolah...96. http://jurnal.radenfatah.ac.id/index.php/tadib/article/view/10. 


\section{Supervision of Strengthening the Mosque-Based Religious Character Education for Students}

Supervision, according to Salim52, is carried out to oversee activities that are in accordance with the stated objectives. The supervision can be done directly or indirectly. Direct supervision in strengthening the character of students is done when the process of implementing program activities takes place. The implementation involves educators and education staff and even the headmaster of madrasa. As an example, in the preparation of midday prayers, all students are monitored by educators who are assisted by the Isslah team to ensure that all students in the Madrasah Aliyah Negeri 2 City of Bandung carry out midday prayers, except for women who are unable to attend. For those who are caught have not made preparations for the midday prayer, there will be given a direct warning. However, for those found out not praying in the congregation will be sanctioned in the form of cleaning and cleaning the mosque, given the task of the call to prayer, cult and also iqamah in a row.

The indirect supervision as told by the religious coach is the supervision that is not realized by the students, namely the supervision of Allah subhanahu wa ta'ala. For students who disobey the rules, and do not perform activities in the mosque, they probably are being free of supervision from educators, but Allah subhanahu wa ta'ala., will not be unaware of the negligence of His creatures so that ultimately those who violate the rules of activity in the mosque will get caught and be sanctioned.

The indirect supervision as told by the religious coach is the supervision that is not realized by the students, namely the

52 A. Salim, "Manajemen Pendidikan Karakter di Madrasah...14. https://www.neliti.com/id/publications/256501/manajemen-pendidikankarakter-di-madrasah. 
supervision of Allah subhanahu wa ta'ala. For students who break the rules of not carrying out activities in the mosque, they are being free of supervision from educators, but Allah subhanahu wa ta'ala. will get caught and be sanctioned.

\section{Evaluation of Strengthening the Mosque-Based Religious Character Education for Students}

Evaluation, as in Salim53, must be carried out continuously. Likewise in Madrasah Aliyah Negeri 2 Bandung City, evaluation of strengthening the mosque-based religious character education of students is carried out continuously. Evaluation of strengthening the mosque-based religious character education of students in Madrasah Aliyah Negeri 2 Bandung City is done through attendance and observation media.

The attendance is for Duha praying and Dhuhr prayer in congregation. Every month, from each class deposits attendance held by the secretary to the Isslah extracurricular department. The attendance was recapitulated. Then the results of the recapitulation are reported to religious leaders, both male and female. After knowing the results of the recapitulation, then a follow-up is carried out for those who experience menstruation improperly by calling by a daughter-in-law, as well as for those who often miss prayer together in congregation.

Besides assessing in the form of attendance list, strengthening the mosque-based religious character education of students is also evaluated in the form of observation. Such observation can be carried out by educators and even fellow

53 A. Salim, "Manajemen Pendidikan Karakter di Madrasah...14. https://www.neliti.com/id/publications/256501/manajemen-pendidikankarakter-di-madrasah. 
students. Assessment in the form of observations is known when researchers conduct interviews with several educators and students.

Observations made by educators are through observing the daily attitudes of students. Observations on attitudes and behaviors related to subjects are carried out by the teacher concerned during the learning process, such as perseverance in learning, self-confidence, curiosity, craft, cooperation, honesty, discipline, care for the environment and as long as students are in madrasa even in madrasa during behavior can be observed by the teacher. The observation evaluation is a form of implication of the strengthening of mosque-based religious character education towards the learning process in the classroom.

Evaluation of the strengthening of the mosque-based religious character education for students in Madrasah Aliyah Negeri 2 Kota Bandung provides a follow-up to the continuation of character education strengthening. Obtained driving factors and inhibiting factors from the implementation of strengthening the religious character education of mosque-based students. These motivating factors include good coordination between madrassa, the commitment of the teaching staff in assisting students during the activity process, and the parents' factors that understand the importance of character. The inhibiting factors that make the process of strengthening character education constrained are like lazy students, bad social environment outside the madrasa, which impacts on students' mindset and there are still parents who are indifferent to their students. 


\section{Conclusion}

The management of strengthening the mosque-based religious character education of students is very important because mosques can be an appropriate alternative environment to instill religious values or character. Strengthening the mosquebased religious character education can strengthen science and technology, faith, and morals of students. The management of strengthening the religious character education of mosque-based students at Madrasah Aliyah Negeri 2 Kota Bandung is carried out through planning, organizing, implementing, monitoring, and evaluating. Planning starts with an awareness of the importance of religious character values, then focuses on programs of strengthening religious character activities such as Duha praying, adhan, iqamah, reciting al-asma al-husna, reciting al-Quran, seven minutes lecture, dzuhr prayer in congregation, dhikr and prayer. The implementation of strengthening the mosque-based religious character education is monitored directly and indirectly and evaluated using attendance and observation methods. This activity is effectively able to develop the character of obedience, responsibility, discipline, cleanliness, neatness, trustworthy, confident, caring, brave and polite.

\section{REFERENCES}

Abdulmuid, Muhibbudin. Manajemen Pendidikan. Batang: Pengging Mangkunegara, 2013.

Angga, Bambang, and A Yusuf. "Implementasi Pendidikan

Karakter dalam Pembelajaran di Sekolah Dasar." Jurnal

Pendidikan Humaniora, 4 No.3, 2016: 134. http://journal.um.ac.id /index.php/jph/article/view/8214.

Badrudin. Manajemen Peserta Didik. Jakarta: Indeks, 2014. Basit, Abdul. "Strategi Pengembangan Masjid bagi Generasi Muda." Jurnal Komunika, Volume 3, Nomor 2, 2009: 271. doi 10.24090/KOMUNIKA. V3I2.130. 
Creswell, Jhon W. Research Design (Pendekatan Kualitatif, Kuantitatif, dan Mixed). Pustaka Pelajar: Yogyakarta, 2013. Effendy, M. Konsep dan Pedoman Penguatan Pendidikan Karakter. Jakarta: Kementerian Pendidikan dan Kebudayaan Republik Indonesia, 2017.

Ginanjar, M Hidayat, and Wartono. "Karakteristik Kepemimpinan Pendidikan Islam Berbasis Masjid." Jurnal Manajemen Pendidikan Islam, Volume I, Nomor 1, 2018: 12. doi: http://dx.doi.org/10.30868/im.v1i01.213.

Hakim, Rosniati. "Pembentukan Karakter Peserta Didik Melalui Pendidikan Bebasis Al-Quran." Jurnal Pendidikan Karakter, Volume IV, Nomor 2, 2014: 124. doi: https://doi.org/10.21831/jpk.v0i2.2788.

Hendriani, S, Susi, Nulhaqim, and A Soni. "Pengaruh Pelatihan dan Pembinaan dalam Menumbuhkan Jiwa Wirausaha Mitra Binaan PT Pelabuhan Indonesia I Cabang Dumai." Jurnal Kependudukan Padjadjaran, 10 No.2, 2008: 157. http://jurnal.unpad.ac.id/kependudukan/article/view/4032.

Irianto, Yoyon Bahtiar. "Strategi Manajemen Pendidikan Karakter." Proceedings of The 4th International Conference Teacher Education. Bandung: UPI, 2010. 380. https://www.google.com/url?sa=t\&source=web \&rct $=\mathrm{j} \& u r l=$ http://file.upi.edu/Direktori/PROCEEDING/UPIIsmail, Asep Usman, Castrawijaya, and Cecep. Manajemen Masjid. Bandung: Angkasa, 2010.

Kristiawan, Muhammad. "Telaah Revolusi Mental dan Pendidikan Karakter dalam Pembentukan Sumber Daya Manusia Indonesia yang Pandai dan Berakhlak Mulia." Jurnal Ta'dib, Volume 18, Nomor 1, 2015: 14. doi: http://dx.doi.org/10.31958/jt.v18i1.274. 
Lickona, Thomas. Educating for Character (Mendidik untuk Membentuk Karakter). Jakarta: Bumi Aksara, 2016.

-. Educating for Character: How Our School Can Teach Respect and Responsbility. New York: Bantam Books, 1991. Machin, A. "Implementasi Pendekatan Saintifik, Penanaman Karakter dan Konservasi Pada Pembelajaran Materi Pertumbuhan." Jurnal Pendidikan IPA Indonesia, 3 No.1, 2014: 29, http://journal. unnes. ac.id/nju /index. php/jpii.

Mahmud, and Tedi Priatna. Kajian Epistemologi, Sistem dan Pemikiran Tokoh Pendidikan Islam. Bandung: Azkia Pustaka Utama, 2008.

Majid, Abdul, and Dian Andayani. Pendidikan Karakter Perspektif Islam. Bandung: PT Remaja Rosdakarya, 2017.

Manullang, Belferik. "Grand Desain Pendidikan Karakter Generasi Emas 2045." Jurnal Pendidikan Karakter, Volume III, Nomor 1, 2013: 2. https://doi.org /10.21831/jpk.v0i1.1283.

Marzuki, Murdiono, and Samsuri. "Pembinaan Karakter Siswa Berbasis Pendidikan Agama di SD dan SMP DIY." Jurnal Kependudukan, 41 No.1, 2011: 7. doi: https://doi.org/10.21831/jk.v41i1.1919.

Mulyasa, E. Manajemen Pendidikan Karakter. Jakarta: Bumi Aksara, 2016.

Najib, M, Novan Ardy Wiyani, and Solichin. "Manajemen Masjid Sekolah sebagai Laboratorium Pendidikan Karakter bagi Peserta Didik." Jurnal Ta'dib, Volume XIX, Nomor 01, 2014: 94. http://jurnal.radenfatah.ac.id /index.php /tadib/article/view/10.

Nez, Alif Laela. "Model Implementasi Pendidikan Karakter Berbasis Kurikulum 2013 di SMA Negeri Kota Tegal." Journal Unnes Educational Management, 3 No.2, 2014: 81. 
https://journal.unnes.ac.id/sju/index.php/ eduman/article/view/4376.

Pawitasari, Erma, Endin Mujahidin, and Nanang Fattah. "Pendidikan Karakter Bangsa dalam Perspektif Islam (Studi Krisis terhadap Konsep Pendidikan Karakter Kementerian Pendidikan dan Kebudayaan." Jurnal Ta'dibuna, Volume 4, Nomor 1, 2015: 3. doi: http://dx.doi.org/10.32832/tadibuna. v4i1.573.

Ramayulis. Ilmu Pendidikan Islam. Jakarta: Kalam Mulia, 2008. Ramayulis, Nizar, and Syamsul. Filsafat Pendidikan Islam:

Telaah Sistem Pendidikan dan Pemikiran Para Tokohnya.

Jakarta: Kalam Mulia, 2010.

Ramdhani, Muhammad Ali. "Lingkungan Pendidikan dalam Implementasi Pendidikan Karakter." Jurnal Pendidikan Universitas Garut, Volume 8, Nomor 1, 2014: 28. https://journal.uniga.ac.id/index.php/JP/article /view/69.

Rusdiana, A. and Qiqi Yulianti Zakiah. Manajemen

Perkantoran Modern. Bandung: Insan Komunika, 2014.

Salim, A. "Manajemen Pendidikan Karakter di Madrasah (Sebuah Konsep dan Penerapannya)." Jurnal Tarbawi, Volume I, Nomor 02, 2015: 10-14. https://www.neliti.com/id/publications/256501/manajemenpendidikan-karakter-di-madrasah.

Samani, Muchlas, and Hariyanto. Konsep dan Model Pendidikan Karakter. Bandung: PT Remaja Rosdakarya, 2017.

Saptono. Dimensi-dimensi Pendidikan Karakter. Salatiga:

Erlangga, 2011.

Setiawati, Nanda Ayu. "Pendidikan Karakter sebagai Pilar Pembentukan Bangsa." Prosiding Seminar Nasional Tahunan . Medan: Fakultas Ilmu Sosial, Universitas Negeri Medan, 2017: 348. http://digilib.unimed.ac.id/id/eprint 127544 . 
Sholiha, T M, Narulita, and Mardihah. "Peran Majelis Dhikr dalam Pembinaan Akhlak Remaja Putri." Jurnal Studi AlQuran, $\quad 10 \quad$ No.2, $2014: \quad 148$. http://journal.unj.ac.id/unj/index.php/jsq/article/view/4445.

Suwito. "Integrasi Nilai Pendidikan Karakter dalam Mata Pelajaran Pendidikan Kewarganegaraan di Sekolah Melalui RPP." Jurnal Ilmiah Civis, II No.2, 2012: 11. http://journal.upgris.ac.id/index.php/civis/article/view/454. Syah, Muhibbin. Psikologi Pendidikan . Bandung: PT Remaja Rosdakarya, 2017.

Sylviyanah, S. "Pembinaan Akhlak Mulia pada Sekolah Dasar (Studi Deskriptif pada Sekolah Dasar Islam Terpadu Nur Al-Rahman." Jurnal Tarbawi, 1 No.3, 2012: 194-195. http://jurnal.upi.edu/tarbawi/view/1301/pembinaan-akhlakmulia-pada-sekolah-dasar-studi-deskriptif-pada-sekolahdasar-islam-terpadu-nur-al-rahman-.html.

Tobroni. "Manajemen dan Kepemimpinan Pendidikan Islam: Mencari Format Baru Manajemen yang Efektif di Era Globalisasi." Jurnal Nadwa, Volume 6, Nomor 1, 2012: 11. doi: http://dx.doi.org/10.21580/nw.2012.6.1.453.

Undang-undang Nomor 20 Tahun 2003 tentang Sistem Pendidikan Nasional

Zulfa, M. "Transformasi dan Pemberdayaan Umat Berbasis Masjid: Studi Pada Masjid Nurussa'adah Salatiga." Jurnal Penelitian Sosial Keagamaan, Volume 9, Nomor 1, 2015: 261. doi: 10.18326/infsl3.v9i1.257-278.

Zulhairi. "Penanaman Nilai-nilai Karakter Peserta Didik di SMA Negeri 1 Padang Panjang." Jurnal al-Fikrah, Volume III, Nomor 2, 2015: 176. doi: http://dx.doi.org/10.31958/jaf.v3i2.400. 